
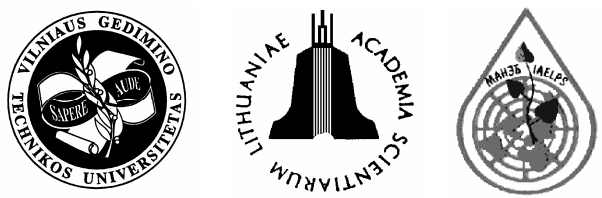

\title{
INVESTIGATION OF OZONE EMISSION AND DISPERSION FROM PHOTOCOPYING MACHINES
}

\author{
Vaida Valuntaitè, Raselė Girgždienè \\ Dept of Physics, Vilnius Gediminas Technical University, Saulètekio al. 11, \\ LT-10223 Vilnius, Lithuania.E-mail:valuntaitev@yahoo.com \\ Submitted 5 Jul 2006; accepted 1 Feb 2007
}

\begin{abstract}
Ozone concentration at the ground level of the atmosphere is constantly monitored, but people spend about 90 per cent of their time inside. Therefore, elevated level of ozone in premises is a matter of great concern. High indoor ozone concentration can cause respiratory failure, hacking cough, pain during deep breath, gnawing in breast and sometimes even nausea. According to the Lithuanian hygiene standard HN 35:2002, a marginal ozone concentration of eight hour average in a workplace is $200 \mu \mathrm{g} / \mathrm{m}^{3}$.

Investigation of ozone distribution from its emission source - a copying machine - in a room were caried out. Simulation showed that an equilibrium state, when ozone formation is equal to ozone decay, was observed only in 40 minutes after the emission source was started up in the room. The study of both vertical and horizontal distribution of ozone was analysed. The results showed that an average concentration near the floor varied in the interval $8-22 \mu \mathrm{g} / \mathrm{m}^{3}$, at the level of the machine it was from 10 to $380 \mu \mathrm{g} / \mathrm{m}^{3}$, and the interval of concentration was $10-110 \mu \mathrm{g} / \mathrm{m}^{3}$ at the ceiling. Assessment of ventilation influence on ozone distribution was performed. Ozone concentration varied in the interval $2-815 \mu \mathrm{g} / \mathrm{m}^{3}$ near the source at a different intensity of copying without ventilation, and using ventilation the concentration decreased up to $0-686 \mu \mathrm{g} / \mathrm{m}^{3}$. It was established that at $0,5 \mathrm{~m}$ distance from a copying machine ozone concentration decreased two times, therefore, a person working with a copying machine should be at a far enough distance from the ozone source in order to reduce its effect on his health.
\end{abstract}

Keywords: copying work intensity, copying machine, ozone, vertical scatter, work premise.

\section{Introduction}

Ozone is especially a nonpersistant gas which causes much trouble for people in the last decades. People spend about $90 \%$ of their time in rooms where ozone concentration is normally much lower comparing to the level outside [1, 2]. Filtering through the walls of a building, the air loses ozone: concentration of this gas in the room can drop up to 250 times, however, people also do not escape the harmful effect of this indoor gaseous pollutant. Copying machines, laser printers, electrostatic air filters, ozone generators and other electric devices that produce ozone are the main anthropogenic sources of ozone emission in rooms [3]. Ozone also forms from ultraviolet (UV) radiation sources (for example, in order to ensure sterility bactericide UV lamps are frequently used in hospitals, labs, food industry). Commercial ozone generators are advertised to remove airborne contaminants and improve indoor environments. This controversial equipment can also be attributed as sources of ozone in a room. Environment Protection Agency (USA) pronounced that this equipment is not sufficiently effective in extermination of contaminants in the air [4]. Supposedly, ozone exterminates the bacteria, mould, formaldehyde, disease-germs, viruses as well as bad smells, for example, smell of tobacco, and leaving only dioxide, water and oxygen. According to the Lithuanian hygiene standard HN 35:2002, the threshold limit value of ozone concentration in workplace air is $200 \mu \mathrm{g} / \mathrm{m}^{3}$, given the average of eight hours [5]. Other sources [6] point out that the limiting allowable concentration of ozone in a workplace is $100 \mu \mathrm{g} / \mathrm{m}^{3}$.

Ozone, due to its high reactivity, is very unstable in rooms. Under normal conditions the half-life of ozone indoors, according to [7], is between 7 and $10 \mathrm{~min}$ and is determined primarily by surface removal and air exchange. Other investigation showed [8] that ozone halflife in a standard office room is less than $10 \mathrm{~min}$.

Ozone forms during copying when a photoreceptor and paper are inserted or discharged as well as when UV lamp operates during photocopying [9]. Since various photocopying processes produce ozone, manufacturers incorporate some type of filtration system (e g, activated carbon filters) to reduce the amount of ozone emitted to the surrounding air. Investigations [10] show that ozone emission can increase between periods of routine maintenance. For example, ozone emissions from five different photocopiers ranged from 16 to $131 \mu \mathrm{g} /$ copy before maintenance compared with 1 to $4 \mu \mathrm{g} / \mathrm{copy}$ after maintenance. According to [11], the average of $40 \mu \mathrm{g} /$ copy of ozone was found to be 
emitted during copying works, and $131 \mu \mathrm{g} /$ copy of ozone was emitted during intensive copying.

When there are no indoor ozone sources, ozone from outside is the main source of ozone in a room [11]. Ozone formation in a polluted environment outside is mainly caused by photochemical reactions between volatile organic compounds $(V O C)$ and nitrogen oxides $\mathrm{NO}_{\mathrm{x}}$ :

$$
\mathrm{NO}_{\mathrm{x}}+V O C+h \mathrm{v} \rightarrow \mathrm{O}_{3}+B,
$$

where $B$ - other compounds; $h v-$ lights quantum.

The ground-level ozone is considered as harmless to vegetation if its concentration does not exceed $60 \mu \mathrm{g} / \mathrm{m}^{3}$ [12]. Investigations carried out in Lithuania show that concentration of ozone in the atmosphere exceeds $100 \mu \mathrm{g} / \mathrm{m}^{3}$ about $9 \%$ of the time [13].

Concentration of ozone in the room depends on concentration of ozone outside. Proportion of these concentrations depends on many factors which are the following: air infiltration or air exchange between environment levels, circulation of air in the room, structure of room surfaces, ozone reaction with other chemical compounds, etc [7, 14, 15]. Furthermore, this proportion varies during the day and is not steady in different days and also depends on the season [16]. Results of investigations performed by hygienists indicate that ozone quantity in the air which is conditioned drops 300-400 times. It is established that the proportion of ozone in the room and outside varied in the limits $0,10-0,80 \pm 0,10$ [1], but other sources state that the limits are narrower, i e $0,3-0,8[17]$.

If concentrations of ozone are from 10 to $20 \mu \mathrm{g} / \mathrm{m}^{3}$ ozone has disinfection characteristics, but higher concentrations of the contaminant are harmful [18]. Other contaminants can exist in the room with ozone. It is established that effect of ozone and aerosol particles on human nostrils, throat and eyes is much stronger comparing to the effect of each contaminant separately [19]. It is known that ozone has negative effect on metals, construction materials, rubber, polymeric materials, lacquered materials, etc [20-22].

The most sensitive to ozone are children and elderly people. It is established that when ozone concentration in air increases by $40 \mu \mathrm{g} / \mathrm{m}^{3}$, the number of children with respiratory disorders increases by 83 per cent [23]. Damaging effect of ozone on human health sometimes is hard to notice, and the first disorders of health can soon disappear, though the damaging effect on health is ongoing [23]. The ailments evidenced at different concentrations of ozone according to [24] are presented in Table 1.

Table 1. Ailments at different concentrations of ozone

\begin{tabular}{c|c}
\hline Concentration of ozone, $\mu \mathrm{g} / \mathrm{m}^{3}$ & Symptoms \\
\hline 100 & Headache \\
\hline 300 & Irritation to eyes \\
\hline 540 & Cough \\
\hline 580 & Thoracic pain \\
\hline
\end{tabular}

The data in the Table show that when ozone concentration reaches $100 \mu \mathrm{g} / \mathrm{m}^{3}$, people can get the headache, and when ozone concentration reaches $580 \mu \mathrm{g} / \mathrm{m}^{3}$, pain in breast can occur.

According to the Directive 2002/3EC EU, the State Members will inform society when the ozone concentration average in an hour reaches $180 \mu \mathrm{g} / \mathrm{m}^{3}$ and give a warning when it reaches $240 \mu \mathrm{g} / \mathrm{m}^{3}$. In order to preserve human health, ozone concentration in environment 25 days a year, given the average of three years, may not exceed $120 \mu \mathrm{g} / \mathrm{m}^{3}$ [25].

The aim of this work is to estimate ozone concentration distribution indoors, including the effect of a direct ozone emission source - a copying machine.

\section{Investigation methodology}

Investigation of ozone concentration variation was carried out in a room of $16 \mathrm{~m}^{2}$ and $42,3 \mathrm{~m}^{3}$, where a source of emission was a copying machine (Fig 1). A maximum intensity of the copying machine was 120 copies per minute. A ventilator of $31 \mathrm{~W}$ was applied for intensifying ozone concentration distribution in the room. Ozone concentration was measured by a commercial ozone analyser $\mathrm{O}_{3} 41 \mathrm{M}$. Operation of this analyser is based on the principle of ultraviolet absorption. Limitations of measuring with an ozone analyser are $0-2000 \mu \mathrm{g} / \mathrm{m}^{3}$, and sensitivity is $1 \mu \mathrm{g} / \mathrm{m}^{3}$. Concentration of ozone was measured continuously and data were presented as a requested average, for example, of 1 minute, 30 minutes, etc. The data were recorded automatically in a computer.

The concentration of pollutants in workplace air, which plays an important role in occupational safety, depends on two basic parameters: emission of a toxic substance and the volume of air that dilutes the emitted substance. Emission depends on many factors, such as the level of technology, kinds of machines, conditions of the process, and so on [26].

The problem is simple when there is only one dangerous compound in the air. The situation becomes much more complicated when there are a few compounds in the air at the same time. The occupational risk assessment appeals to the data of relationship between measured concentration of toxic substances in workplace air and the threshold limit value (TLV) of this substance. The summary level of exposure is expressed by the sum of quotients: concentration of each compound to its hygienic standard:

$$
\sum_{i} C_{i} / T L V_{i}
$$

Conditions at a workplace are safe when the result of this expression is smaller than 1 . In our case only one pollutant was estimated, i e ozone.

It is known [1] that ozone concentration in the room $C_{p}$ depends on its concentration $C_{l}$ outside, on velocity $v_{x}$ at which the air in the room is replaced by the air from outside, on indoor ozone generation $Q$, deposition velocity $v_{d}$ at which ozone is eliminated from air because of contact with surfaces, and on chemical reactions among ozone and other chemical materials in the air. Relationship between ozone concentration change in the room and 


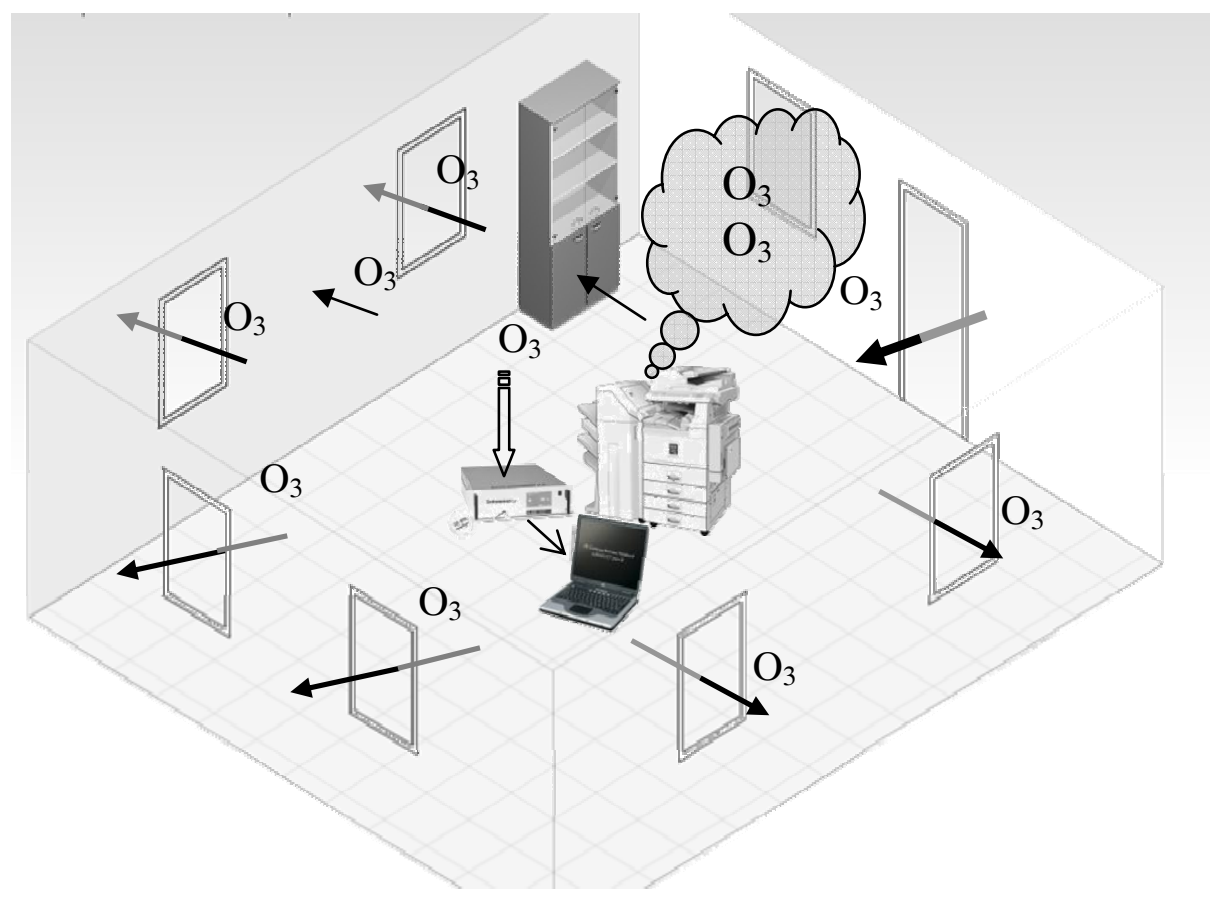

Fig 1. Ozone formation and decay pathways in room during experiment

ozone sources and sinks can be formulated as follows:

$$
\frac{d C_{p}}{d t}=v_{x} C_{l}+Q-C_{p}\left(v_{d} \frac{S}{V}+v_{x}+\sum_{i} k_{i} C_{i}\right),
$$

where $C_{p}$-indoor ozone concentration, $\mu \mathrm{g} / \mathrm{m}^{3} ; \mathrm{t}$ - time, $\mathrm{h}$; $C_{l}$ - outdoor ozone concentration, $\mu \mathrm{g} / \mathrm{m}^{3} ; v_{x}$ - the rate at which the indoor air is replaced with outdoor air (air exchange rate), $\mathrm{h}^{-1} ; Q$ - rate at which ozone is generated within the room, $\mu \mathrm{g} / \mathrm{m}^{3}$ per hour; $v_{d}$-deposition rate, $\mathrm{m} / \mathrm{h}$; $S$ - total surface area within the room, $\mathrm{m}^{2} ; V$ - volume of the room, $\mathrm{m}^{3} ; C_{i}-$ concentration of chemical material $i$ with which ozone could react in a room, $\mu \mathrm{g} / \mathrm{m}^{3} ; k_{i}-$ velocity of reaction between ozone and chemical material $i$ in the room expressed in $\mathrm{m}^{3} / \mu \mathrm{g}$ per hour.

Ozone chemical reactions with other pollutants in the room often have no influence on ozone scatter in a closed space, therefore, the last term in the formula sometimes is ignored. Therefore, this term was not estimated during estimation of ozone level in the experiment. Therefore, the simplified formula (2) becomes as follows:

$$
\frac{d C_{p}}{d t}=v_{x} C_{l}+Q-C_{p}\left(v_{d} \frac{S}{V}+v_{x}\right)
$$

The capacity of a source of ozone (a copying machine), which, according to the project [11], can fluctuate from 0 to $1350 \mu \mathrm{g} / \mathrm{copy}$ (the average is $259 \mu \mathrm{g} / \mathrm{copy}$ ), has the biggest influence on ozone frequency in the room. Furthermore, the speed of ozone replacement in the room with the air from outside $v_{x}$, which fluctuates from 0,10 to $0,80 \pm 0,10$ [1], influences the ozone scatter. Parameters of the room (volume, area) also perform an important role for ozone dispersion in the room.

\section{Measurement results}

The investigation was carried out at a different intensity of copying. Three copying machines and one laser printer operated in the room. The ozone emmission from the laser printer was insufficient and was mostly switched off during our investigation. Intensity of the copying process was grouped into five clusters:

1 - copying is not in progress;

2 - from 1 to 30 copies/min;

3 - from 31 to 60 copies/min;

4 - from 61 to 90 copies/min;

5 - from 91 to 120 copies/min.

Ozone concentration was measured at two distances from the source: nearby, only at some centimetres and at 1,5 meter. Ozone concentration dependence on copying work intensity is presented in Fig 2.

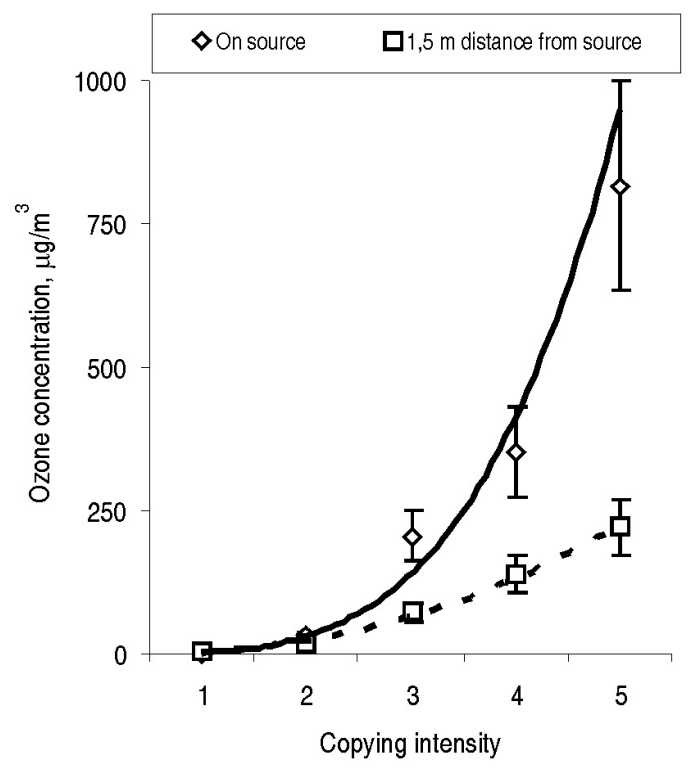

Fig 2. Change of ozone concentration with increase of copying intensity 
The obtained data showed that the concentration of ozone increased with the increase of copying work intensity (Fig 2). Ozone concentration level near the source and at $1,5 \mathrm{~m}$ distance from the source can be expressed by formulas 4 and 5, respectively.

$$
\begin{aligned}
& C=2.27 i^{3.75}, \\
& C=4.44 i^{2.44},
\end{aligned}
$$

where $C$ - indoor ozone concentration, $\mu \mathrm{g} / \mathrm{m}^{3} ; i-$ number of cluster, and $i$ varied from 1 to 5 in our case.

When receding from the ozone emission source - a copying machine - the concentration of ozone in the room decreased. These results were compared with the theoretical evaluation of ozone concentration under a different copying itensity. The calculations were performed in accordance with equation 2 . The outdoor ozone concentration during the experiment varied in a narrow interval with the average of $40 \pm 2 \mu \mathrm{g} / \mathrm{m}^{3}$.

That low value is characteristic of the winter season when the experiment was carried out. The rate at which the indoor air was replaced with outdoor air was evaluated as 1 per hour or 0,017 per minute. This value was chosen in accordance with the results in [27] where air exchange rate was evaluated in 300 office rooms and was found to be most frequently in the range of 0,5 to 1,2 air changes per hour. The copying device was after a recent periodic maintenance, so the emission of ozone did not exceeded $40 \mu \mathrm{g}$ per copy. Ozone deposition rate on the surface was evaluated as $0,051 \mathrm{~cm} / \mathrm{s}$, i e for a standard office room [7]. The theoretical calculation of the ozone concentration variation was made for four different levels of copying intensity which were named as clusters. The obtained data are presented in Fig 3 .

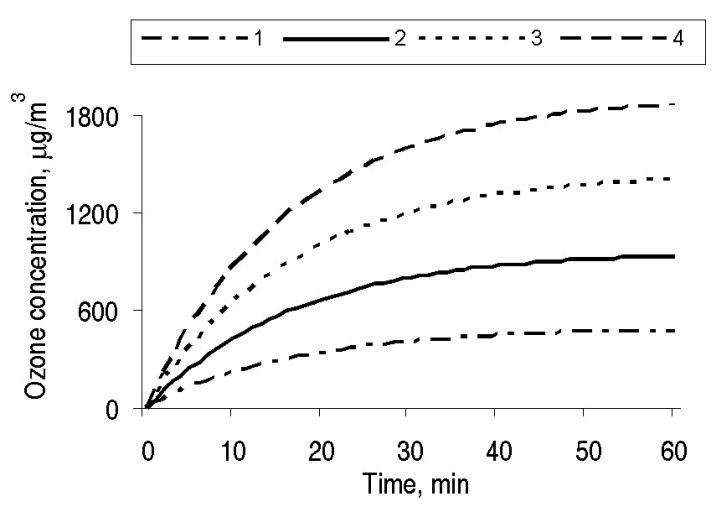

Fig 3. Simulated ozone concentration at four different levels of copying intensity

Analysis of the data showed that the ozone distribution under these conditions indicated initially rapid rise and by $0,5 \%$ reduced amount of ozone after 40 minutes. The simulation revealed that ozone accumulation in the office room is proceed under the equation

$$
C=a / b\left(1-e^{-b t}\right),
$$

where $a=v_{x} C_{l}+Q$ and $b=v_{d} \frac{S}{V}+v_{x}$ and the saturation, i e equilibrium state when ozone production is equal to ozone decay (difference of less than 0,5\%), is observed after about 40 minutes at all the four clusters.

The copying process was carried out with pause during the experiment, and for this reason ozone was unevenly spread in the room, i e the measurements were performed not during the equilibrium state of ozone. That situation mostly exists during practical activity. Therefore, the measurements of ozone distribution in the room were performed at a different height and distance from the source to investigate possible risk of ozone to a human during copying. The investigation was also carried out with and without a ventilator.

Distribution of ozone concentration by the copying height is presented in Fig 4.

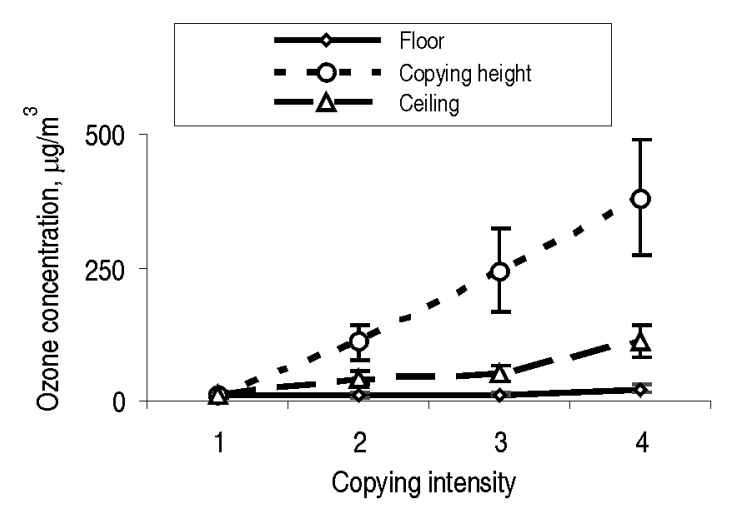

Fig 4. Ozone concentration in room by copying height

The most intensive scatter of ozone is at the level of the copying machines $(1 \mathrm{~m})$, the maximum of $380 \mu \mathrm{g} / \mathrm{m}^{3}$ was detected here (when both copying machines were operating). It was observed that ozone diffused from the copying machines toward the ceiling, and only a minimum quantity settled near the ground. Near the ground concentration of ozone ranged in the interval from 8 to $22 \mu \mathrm{g} / \mathrm{m}^{3}$, and near the ceiling the concentration ranged from 10 to $110 \mu \mathrm{g} / \mathrm{m}^{3}$.

Analysis of ozone concentration recurrence in the given interval was performed. In the room without an ozone emission source the frequency distribution can be described as Gaussian one. As in this case the copying machine operated in the room, the frequency distribution cannot be described by normal (Gaussian) distribution. Fig 5 shows how many times the concentration of ozone recurred in the relevant interval in the office room during working hours.

Since normally copying was not intensive during the investigation (from 1 to $30 \mathrm{copies} / \mathrm{min}$ ), the most frequent concentration of ozone was recorded in the interval $0-100 \mu \mathrm{g} / \mathrm{m}^{3}$ the recurrence of which was $48 \%$. Ozone concentration recurrence in the interval 1000 $1100 \mu \mathrm{g} / \mathrm{m}^{3}$ was less than $1 \%$.

The horizontal distribution of ozone concentration from a copying machine was carried out. The concentration of ozone was measured at the copying machine and at a distance of $0,5 \mathrm{~m}$ as well as at a distance of $1 \mathrm{~m}$ from the ozone emission source. Measurements at the 
copying machine were carried out by getting the Teflon tube of the ozonometer towards the copying machine at a distance of $10 \mathrm{~cm}$ from the discharge of the copying machine. Maximum ozone concentration of $513 \mu \mathrm{g} / \mathrm{m}^{3}$ was detected when ozone concnetration was measured near the copying machine; at a distance of $50 \mathrm{~cm}$ from the copying machine maximum concentration was $94 \mu \mathrm{g} / \mathrm{m}^{3}$, and at a distance of $1 \mathrm{~m}$ it was $193 \mu \mathrm{g} / \mathrm{m}^{3}$, but average concentrations at both distances were very close. This fact shows that maximum concentration of ozone is at the copying machine and drops when receding from it. Increase of ozone concentration at a distance of $1 \mathrm{~m}$ could be caused by the fact that the ozonometer was in front of the most intensive copying machine at a distance of $2 \mathrm{~m}$.

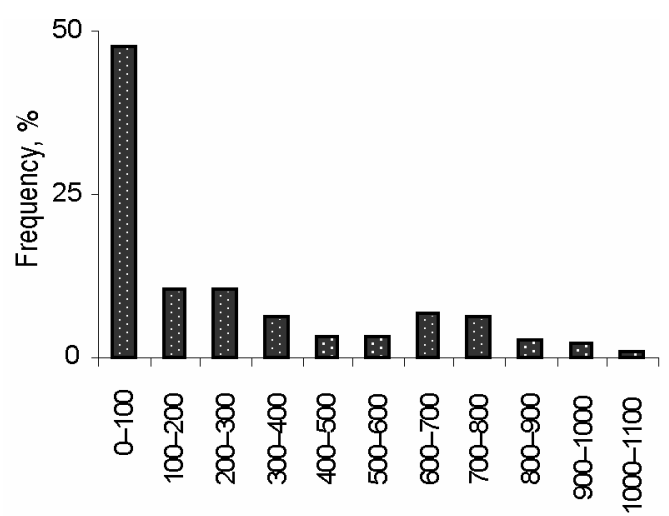

Ozone concentration interval, $\mu \mathrm{g} / \mathrm{m}^{3}$

Fig 5. Distribution of ozone concentration frequency in room

With the aim of evaluating the influence of ventilation on ozone concentration changes a ventilator of $31 \mathrm{~W}$ was used during the investigation. The comparison of ozone concentration distribution in the room near the copying mashine was carried out: with ventilator "on" and with ventilator "off” (Figs 6 and 7).

Ozone concentration in the room with a source of ozone emission - a copying machine - was higher when a ventilator was "off", and lower when a ventilator was "on".

After positioning the ozonometer at $1,5 \mathrm{~m}$ distance average concentrations in a ventilated and unventilated room were equal, respectively, to $52 \mu \mathrm{g} / \mathrm{m}^{3}$ and $90 \mu \mathrm{g} / \mathrm{m}^{3}$. This shows that a ventilator reduced the ozone concentration 1,8 time at a distance of 1,5 m.

Maximum short-term ( $5 \mathrm{~min}$ ) ozone concentrations differed insignificantly and fluctuated around $1025 \mu \mathrm{g} / \mathrm{m}^{3}$ comparing working near a copying machine in a room with and without ventilation. After positioning the ozonometer at $1,5 \mathrm{~m}$ distance maximum concentrations in a ventilated and unventilated room were $115 \mu \mathrm{g} / \mathrm{m}^{3}$ and $350 \mu \mathrm{g} / \mathrm{m}^{3}$, respectively.

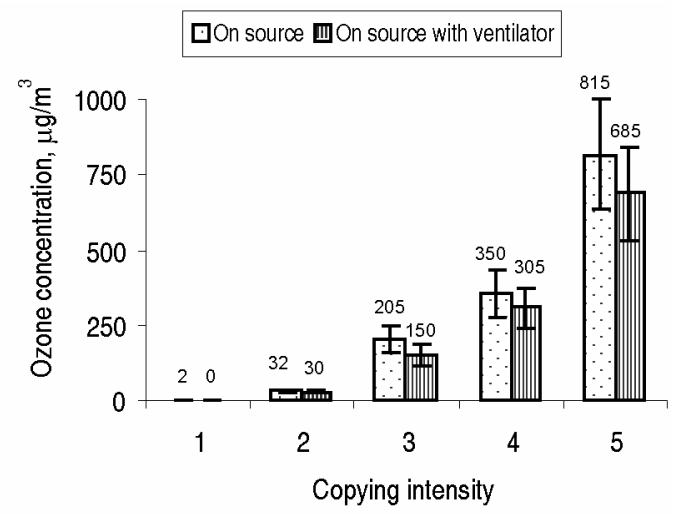

Fig 6. Distribution of ozone at different regimes of copying process intensity in ventilated and unventilated room

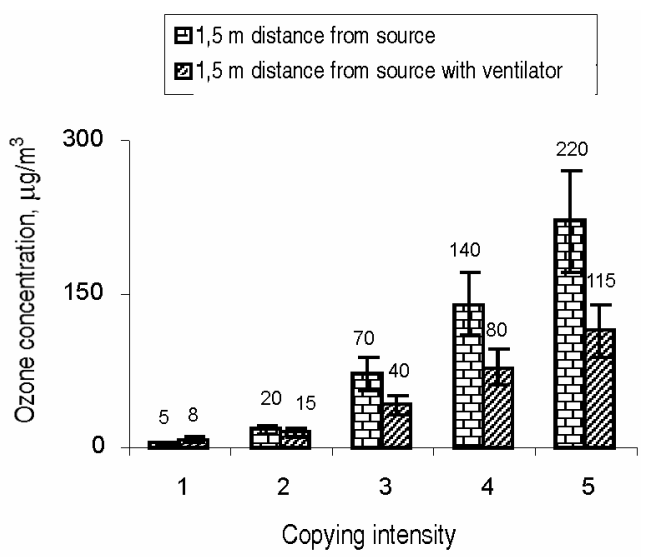

Fig 7. Horizontal distribution of ozone concentration at $1,5 \mathrm{~m}$ distance from source in ventilated room and unventilated room

Ozone concentrations decreased significantly near and at a distance of 1,5 $\mathrm{m}$ from the source when copying machines were turned off, i e from 7:00 $\mathrm{p} \mathrm{m}$ to 8:00 a m. Both measured ozone concentration values (in a ventilated and unventilated room) fluctuated from 0 to $9 \mu \mathrm{g} / \mathrm{m}^{3}$. The study results of horizontal ozone concentration scatter are provided in Table 2.

Assessment of likely occupational risk for people working with a copying machine was made. According to formula 1 , for some days this ratio reached even 1,46 . It indicates that sometimes conditions are not safe.

Table 2. Results of horizontal distribution of ozone concentration, $\mu \mathrm{g} / \mathrm{m}^{3}$

\begin{tabular}{l|c|c|c|c}
\hline \multicolumn{1}{c|}{ Experiment conditions } & \multicolumn{2}{c}{$\begin{array}{c}\text { Average during working hours } \\
\text { (from 8:00 a m to 7:00 p m) }\end{array}$} & \multicolumn{2}{c}{ Hourly maximum } \\
\hline Distance from the source, $\mathrm{m}$ & 0,1 & 1,5 & 0,1 & 1,5 \\
\hline Unventilated room & 350 & 62 & 820 & 151 \\
\hline Ventilated room & 320 & 40 & 520 & 87 \\
\hline
\end{tabular}




\section{Conclusions}

1. It is established that ozone concentration increases with the increase of the copying process intensity in an office room. The concentration changes can be aproximated by the power function.

2. It wss established that an average concentration of ozone at the level of a copying machine was $185 \pm 56 \mu \mathrm{g} / \mathrm{m}^{3}$, and near the ceiling and ground $-55 \pm 4$ and $13 \pm 15 \mu \mathrm{g} / \mathrm{m}^{3}$, respectively.

3. Ozone concentration decreases with the increase of distance from a copying machine. At 1,5 m distance from the source the concentration of ozone varied in the interval of $90 \pm 20 \mu \mathrm{g} / \mathrm{m}^{3}$, whereas at the same time an average ozone concentration near the source was $280 \pm 63 \mu \mathrm{g} / \mathrm{m}^{3}$.

4. The use of a ventilator reduces an average ozone concentration near the source up to $50 \mu \mathrm{g} / \mathrm{m}^{3}$, from $280 \pm 63$ to $235 \pm 52 \mu \mathrm{g} / \mathrm{m}^{3}$.

5. Indoor ozone concentration in the presence of an anthropogenical ozone source - a copying machine - can exceed the threshold limit value which is not dangerous for human helth.

6. The investigation results show that receding from an ozone emission source - a copying machine - the concentration of ozone in a room decreases. It is established that at $0,5 \mathrm{~m}$ distance from a copying machine ozone concentration decreases two times, therefore, a practical conclusion could be drawn that persons working with a copying machine should be at a far enough distance from the ozone source in order to reduce its effect on their health.

\section{References}

1. HAYES, R. S. Use of an Indoor Air Quality Model (IAQM) to Estimate Indoor Ozone Levels. Journal of Air and Waste Management Association, 1991, Vol 41, No 2, p 161-170.

2. SUNDELL, J. On the history of indoor air quality and health. Indoor Air, International Journal of Indoor Environment and Health, 2004, Vol 14, p 51-58.

3. Ozone. Indoor ozone. North Carolina Department of Health and Human Services. Available at: <http://www.epi.state.nc.us/epi/oee/ozone/indoor.html>

4. WALDMAN, J. Health Hazards of Ozone-generating Air Cleaning Devices. IAQ Fact Sheet, 1998. Available at: $<$ http://www.cal-iaq.org/o3_fact.htm>

5. Dèl Lietuvos higienos normos HN 35:2002 „Gyvenamosios aplinkos orą teršiančių medžiagų koncentracijų ribinès vertės" patvirtinimo. Lietuvos Respublikos sveikatos apsaugos ministro ir Lietuvos Respublikos socialinès apsaugos ir darbo ministro isakymas 645/169. Valstybès žinios, Nr. 110-4008, 2001.

6. Encyclopedia of Labour Protection and Hygiene. Moscow: Protizdat (in Russian), 1986. 663 p.

7. WESCHLER, CH. J. Ozone in Indoor Environments: Concentration and Chemistry. Indoor Air, 2000, Vol 10, p 269-288.

8. Ozone Treatment for Cooling Towers. Department of Energy by the Pacific Northwest National Laboratory, 1995, p 1-28. Available at:
<http://66.249.93.104/search?q=cache:lsR92If1kbQJ:ww w.spartanwatertreatment.com/articles/Ozone-Treatmentfor-Cooling-Towers-Federal-Technology-Alert.pdf+ozone +half-life + in + the + office $\& h l=1 t \& g l=1 t \& c t=c \operatorname{lnk} \& c d=65>$

9. BROWN, S. K. Assessment of Pollutant Emissions from Dry-Process Photocopiers. Indoor Air, 1999, Vol 9, p 259-267.

10. LEOVIC, K. W.; SHELDON, L. S.; WHITAKER, D. A.; HETES, R. G.; CALCAGNI, J. A. and BASKIR, J. N. Measurement of indoor air emissions from dry-process photocopy machines. Journal of Air and Waste Management Association, 1996, Vol 46, p 821-829.

11. HETES, R.; MOORE, M.; NORTHEIM, C. Office Equipment: Design, Indoor Air Emissions, and Pollution Prevention Opportunities. EPA, 600, SR-95, 045, 1995, p 1-5.

12. BAKAS, A.; BALTRĖNAS, P.; GIRGŽDIENĖ, R. and KAULAKYS, J. Investigation of the ozone formation in two-stage electrostatic filters. Atmospheric Physics, 1995, Vol 17, No 1, p 75-81.

13. GIRGŽDIENĖ, R. and GIRGŽDYS, A. Variations of the seasonal ozone cycles in the Preila station over the 19882001 period. Environmental and Chemical Physics, 2003, Vol 25, No 1, p 11-16.

14. GRØNTOFT, T.; HENRIKSEN, J. F.; SEIP, H. M. The humidity dependence of ozone deposition onto a variety of building surfaces. Atmospheric Environment, 2004, Vol 38, p 59-68.

15. LEE, S. C.; SANCHES, L.; HO, K. F. Characterization of VOCs, ozone, and PM10 emissions from office equipment in an environmental chamber. Building and Environment, 2001, Vol 36, p 837-842.

16. SEINFELD, J. H. Atmosferic chemistry and physics of air pollutions. USA, $1986.738 \mathrm{p}$.

17. WOLKOFF, D. Photocopier and indoor air pollution. Atmospheric Environment, 1999, Vol 33, p 2129-2130.

18. New Directions: Ozone-initiated reaction products indoors may be more harmful than ozone itself. Atmospheric Environment, 2004, Vol 38, p 5715-5716.

19. MØLDAVE, L.; KJÆRGAARD, S.; SIGSGAARD, T.; LEBOWITZ, M. Interaction between ozone and airborne particulate matter in office air. Indoor Air, 2005, Vol 15, p 383-392.

20. Canadian Council of Ministers of the Environment. Effects of Ozone on Materials. March 2003, p 1-5. Available at: <http://www.ccme.ca/assets/pdf/scrvw_execsmry _oz_effects_materials_e.pdf>

21. ATLSHULlER, A. P.; WARTBURG, F. W. The interaction of Ozone with Plastic and Metallic Materials in a Dynamic Flow System. Int. J. Air and Water Poll. Pergamon Press, 1961, Vol 4, No 1/2, p 70-78.

22. CASS, G. R.; DRUZIK, J. R.; GROSJEAN, D.; NAZAROFF, W. W.; WHITMORE, P. M.; WITTMAN, C. L. Protection of Works of Art From Atmopheric Ozone. The Getty Conservation Institute. Research in Conservation 5, 1989, p 1-94.

23. GILLILAND, F. D.; BERHANE, K.; RAPPAPORT, E. B.; THOMAS, D. C.; AVOL, E.; GAUDERMAN, W. J.; LONDON, S. J.; MARGOLIS, H. G.; Mcconnell, R.; ISLAM, K. T.; PETERS, J. M. The effects of ambient air pollution on school absenteeism due to respiratory illnesses. Epidemiology, 2001, Vol 12, p 43-54. Available at: $<$ http://www.ewg.org/sites/asthmaindex/about/kidshealth. php> 
24. SUNDEL, J. On the history of indoor air quality and health. Indoor Air, 2004, Vol 14, p 51-58.

25. Directive 2002/3/EC of the European Parliament and of the Council of 12 February 2002 relating to ozone in ambient air. Official Journal L 067, 09/03/2002.

26. BENCZEK, K. M.; GAWĘDA, E.; KURPIEWSKA, J. Prediction of Toxic Substances Emission for Occupational
Exposure Assessment. International Journal of Occupational Safety and Ergonomics, 2000, p 35-43.

27. PERSILY, A. Ventilation Rates in Office Buildings. In IAQ '89, The Human Equation: Health and Comfort, Atlanta, GA, American Society of Heating, Refrigerating, and Air Conditioning Engineers, 1989, p 128-136.

\section{OZONO EMISIJOS IR SKLAIDOS IŠ KOPIJAVIMO APARATŲ TYRIMAI}

\section{Valuntaitè, R. Girgždienè}

S antrauka

Lauke esančio ozono koncentracijos yra nuolatos stebimos ir matuojamos. Tačiau žmogus apie 90 \% viso laiko praleidžia patalpoje, todèl didelès ozono koncentracijos patalpoje kelia ypač dideli susirūpinimą. Didelès ozono koncentracijos patalpos ore gali būti pavojingos žmogaus sveikatai ir sukelti kvėpavimo nepakankamuma, sausą kosuli, skausmą giliai ikvepiant, krūtinès maudimą ir kartais netgi pykinimą. Pagal Lietuvos higienos normą HN 35:2002 ribinè ozono koncentracija darbo vietoje yra $200 \mu \mathrm{g} / \mathrm{m}^{3}$, imant 8 h vidurki.

Ištirta ozono sklaida patalpoje nuo ozono emisijos šaltinio - kopijavimo aparato. Apskaičiuotos ozono kaupimosi kreivès tiriamoje patalpoje, parodyta, kad ozono koncentracija vienodai pasiskirsto patalpoje tik maždaug po 40 min nenutrūkstamo kopijavimo. Ištirta, kaip ozono koncentracija pasiskirsto patalpoje pagal aukštị ir atstumą nuo šaltinio jam veikiant trumpiau nei $40 \mathrm{~min}$. Tiriant vertikaluji ozono koncentracijos pasiskirstyma, nustatyta, kad vidutinè koncentracija prie grindų kito nuo 8 iki $22 \mu \mathrm{g} / \mathrm{m}^{3}$, kopijavimo aparato aukštyje - nuo $10 \mathrm{iki} 380 \mu \mathrm{g} / \mathrm{m}^{3}$, o prie lubu $-10-110 \mu \mathrm{g} / \mathrm{m}^{3}$ intervalu. Ivertinta ventiliacijos itaka ozono koncentracijos sklaidai patalpoje. Tyrimai parodè, kad, esant skirtingam kopijavimo intensyvumui, ozonas prie šaltinio kito $2-815 \mu \mathrm{g} / \mathrm{m}^{3}$ intervalu, o, veikiant ventiliatoriui, ozono koncentracijos intervalas sumažèjo nuo 0 iki $685 \mu \mathrm{g} / \mathrm{m}^{3}$. Remiantis tyrimų rezultatais, pateikta praktinè išvada, kad žmogus, net trumpa laiką dirbantis su kopijavimo apratais, privalo būti kuo toliau nuo jo (kiek tai leidžia kopijavimo procesas).

Reikšminiai žodžiai: kopijavimo intensyvumas, kopijavimo aparatas, ozonas, vertikalioji sklaida, darbo patalpos.

\section{ИССЛЕДОВАНИЕ ЭМИССИИ И ДИСПЕРСИИ ИЗ КОПИРОВАЛЬНЫХ УСТРОЙСТВ}

\section{В. Валунтайте, Р. Гиргждене}

Р ез юм е

Концентрация озона в атмосфере постоянно контролируется и измеряется, однако люди приблизительно 90 процентов времени проводят в помещениях.

Высокие концентрации озона в закрытых помещениях, в которых люди проводят длительное время, могут быть опасны для их здоровья и вызывать недостаточность дыхательного процесса, сухой кашель, причинять боль при вдохе, боли в груди и даже тошноту. Согласно стандарту гигиены HN 35:2002 Литовской Республики пороговая концентрация озона на месте работы составляет 200 мкг/м³ при среднем рабочем времени в восемь часов.

В работе исследована эмиссия озона от копировальной машины и распределение его концентрации в закрытом помещении. Рассчитаны кривые накопления озона в исследуемом помещении и показано, что относительно однородное распределение О3 устанавливается спустя 40 минут непрерывного копирования. Экспериментально исследованы вертикальные и горизонтальные распределения концентрации озона в помещении. Определено, что средняя концентрация этого загрязнителя около пола изменялась от 8 до 22 мкг/м ${ }^{3}$, на уровне копировальной

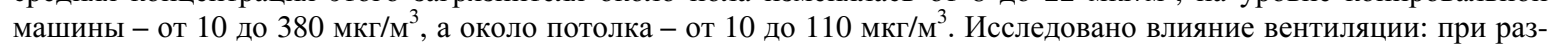
ной интенсивности копирования без вентиляции концентрация озона около источника менялась в интервале $2-$ 815 мкг $/ \mathrm{m}^{3}$, а при включенной вентиляции она понижалась и менялась от 0 до 685 мкг/м ${ }^{3}$. На основании полученных результатов показано, что обслуживающий персонал копировальных машин должен находиться как можно дальше от аппарата (насколько позволяет процесс копирования). Это значительно снизит негативное влияние озона на их здоровье.

Ключевые слова: интенсивность копирования, копировальная машина, озон, вертикальная эмиссия, рабочее помещение.

Vaida VALUNTAITÉ. Doctoral student, Dept of Physics, Vilnius Gediminas Technical University (VGTU).

Doctoral student (environmental protection), VGTU, since 2005. Master of Science (technosphere ecology) (2004), Bachelor of Science (environmental engineering) (2002), VGTU. Research interests: ecology, envoronmental protection.

Raselė GIRGŽDIENĖ. Dr, Dept of Physics, Vilnius Gediminas Technical University (VGTU).

Doctor of Science (environmental physics), 1986. Publications: more than 60 scientific publications. Research interests: air quality, pollutant transport and transformation, indoor and outdoor problems, monitoring, ozone variations, environmental assessment. 